\title{
Entomology contribution in animal immunity: Determination of the crude thoraxial glandular protein extract of Stomoxys calcitrans as an antibody production enhancer in young horses
}

\author{
L. Rumokoy, ${ }^{1}$ S. Adiani, ${ }^{2}$ G.J.V. Assa, ${ }^{2}$ W.L. Toar, ${ }^{2}$ J.L. Aban ${ }^{3}$ \\ ${ }^{1}$ Entomology Study Program, Postgraduate of Sam Ratulangi University, Manado; ${ }^{2}$ Animal Science Faculty, Sam \\ Ratulangi University, Manado, Indonesia; ${ }^{3}$ Area of Parasitology, Faculty of Pharmacy, University of Salamanca, Spain
}

\begin{abstract}
This experiment was conducted to evaluate the level of antigens protein contained in the crude thoraxial glandular protein (TGP) extract of Stomoxys calcitrans which function as immunity enhancer in young horses. The detection of protein content of the thoraxial glandular samples was performed by using a spectrophotometer Nano Drop-1000. This result showed that the lowest level of antigen protein was $0.54 \mathrm{mg} / \mathrm{mL}$, the highest was $72 \mathrm{mg} / \mathrm{mL}$, and the average was $0.675 \mathrm{mg} / \mathrm{mL}$. Six foals were used and divided into two groups. The first group was treated with a solution of
\end{abstract}

Correspondence: Laurentius Rumokoy, Entomology Program of Postgraduate School, Sam Ratulangi University, Campus of Unsrat, Manado 95115, Indonesia.

E-mail: rumokoy@msn.com

Key words: Entomology, Immunoglobulin, Stomoxys calcitrans.

Acknowledgments: the authors would like to thank the Director of Sentrum Agraris Lotta (SAL) Pineleng, Indonesia for facilitating our collection of stable flies in the SAL area. The same regards are addressed to the Director of the CIETUS who has allowed us to make the laboratory observations related to this research at the CIETUS, Salamanca. The authors are also thankful for the correction of the English language provided by Mrs. Virginia Le Bihan, a French FIDESCO volunteer in Manado.

Contributions: the authors contributed equally.

Conflict of interests: the authors declare no potential conflict of interests.

Received for publication: 15 September 2017.

Revision received: 30 November 2017.

Accepted for publication: 30 November 2017.

(C) Copyright L. Rumokoy et al., 2017

Licensee PAGEPress, Italy

Journal of Entomological and Acarological Research 2017; 49:7074 doi:10.4081/jear.2017.7074

This article is distributed under the terms of the Creative Commons Attribution Noncommercial License (by-nc 4.0) which permits any noncommercial use, distribution, and reproduction in any medium, provided the original author(s) and source are credited.
$100 \mu \mathrm{g}$ of TGP by subcutaneous injection, the other group acted as control. The TGP extract was injected on the first day of the experiment. Three $\mathrm{ml}$ of blood were sampled from the jugular vein on the $14^{\text {th }}$ day after TGP injection. The blood sampled was centrifuged and its serum placed in micro-tubes to observe the IgG level. The injection of TGP had a significant effect on the IgG level of the experiment animals $(\mathrm{P}<0.05)$. This experiment emphasized an important relation between entomology and animal husbandry; health improvement in the young animals was observed after the injection of the insect antigen, so it can be concluded that crude thoraxial glandular proteins of $S$. calcitrans can be used to improve the immunoglobulin-G circulation in foals.

\section{Introduction}

The flies, especially the ones belonging to the family Muscidae, are often considered as bio-transmitters of pathogen microbes both in animals (Brits et al., 2016; Iqbal et al., 2014; Rumokoy et al., 2017) and experiment plants (Kalaikesar et al., 2016; Wasala et al., 2013; Talley et al., 2009). The importance of research work in entomology in relation with mammalian immunity was already described (Obame-Nkoghe et al., 2017; Toar et al., 2017); the stable fly Stomoxys calcitrans (Diptera, Muscidae) plays an important role as disease vector in humans and animals. S. calcitrans is a blood feeding insect, injecting its saliva produced in the salivary glandular located in the thoraxial segment (Baldachino et al., 2013).

The organic components of saliva include digestive enzymes, helping the insect to acquire a meal from the blood. Anticlotting proteins with multiple isoforms were found in the saliva of horn flies (Cupp et al., 2009; Untalan et al., 2006). The saliva of S. calcitrans has been used for farm animal defense against the insect itself as pest. The injection of crude saliva-gland extract of $S$. calcitrans in cows showed an increase of IgG antibodies (Ameri et al., 2008) minimizing the damage caused by $S$. calcitrans to experiment animals.

These scientific results in entomology gave a solution against the hypo-globulinemia in young horses. Young animals affected by hypo-globulinemia were easily infected by the pathogenic microbes and parasites from the ex-utero environment (Rumokoy \& Toar, 2014). According to Grongnet (1996) this condition in neonates often followed a failure of passive transfer that caused a high mortality rate.

Based on this background we carried out this study to evaluate the antigen proteins in the crude thoraxial glandular protein 
extract and the consequences of the TGP treatment on the serum IgG level of foals.

\section{Materials and methods}

The sampling of $C$. calcitrans was carried out at the farm of Sentrum Agraris Lotta (SAL) in Manado, North Sulawesi, Indonesia. Six experiment foals were reared in traditional farms in the Minahasa region, North Sulawesi, Indonesia. The identification of the antigen protein was conducted at the Laboratory of Immunology and Parasitology at the University of Salamanca, Spain.

\section{Preparation of the thoraxial glandular protein extract}

The extraction of the crude TGP of $S$. calcitrans was adapted from procedure of Swist et al. (2002). The dissection of Stomoxys calcitrans was run in a petri. This dissection was realized under a photonic microscope, model Meiji EMZ-TR. After obtaining TGP, we proceeded to its identification with a ND-1000 spectrophotometer and the separation of protein molecules by a SDS-PAGE.

\section{Animals and analysis of the immunoglobulin-G serum}

Six foals of local breed, under traditional rearing were used in this experiment. The blood serum IgG level of the animals was analyzed by using the Single Radial Immuno-Diffusion method, starting with the following procedures: filling four wells with 15 $\mu \mathrm{L}$ of standard solution, and then filling the trench (well) gel with a $15 \mu \mathrm{L}$ sample of blood plasma. Then the plate was moved into the incubator box at a temperature of $30-40^{\circ} \mathrm{C}$, left there for about 16 hours so that the antibodies could diffuse in the gel containing the anti-IgG antigen. After that, the plate was filled with a solution of $2 \%$ acetic acid and incubated for one minute. The following stage involved rinsing the drain plate and the gel twice using deionized water. Then, for the last time, the plate was filled with deionized water or distilled water and incubated for approximately ten to fifteen minutes. The last step was measuring the IgG content based on the radius precipitation.

\section{Research procedures}

The foals were divided into two groups: one group was treated with a subcutaneous injection of $100 \mu \mathrm{g}$ of crude TGP, the other group acted as control. Fourteen days after the injection, approximately $3 \mathrm{ml}$ blood samples were collected through the jugular vein. The blood was centrifuged immediately and then serum was collected in an Eppendorf tube to be prepared for the $\operatorname{IgG}$ analysis.

\section{Statistical analysis}

To evaluate the effect of TGP on the IgG level of the foal serum, the means of sampling used with the control group were compared to those of the treated group by a t-test (Zar, 1996).

\section{Results}

The TGP substances indicated on the SDS-PAGE a content of protein antigen with a molecular weight of $27 \mathrm{kDal}$ (Figure 1). The fore-mentioned identified weight of the protein substance belonging to the TGP of the stable fly (S. calcitrans) appeared similar to the one reported by Wang et al. (2009) and Ueti et al. (2007)

The analysis of protein content of the thoraxial glandular extract carried out by using a spectrophotometer ND-1000 showed that the lowest level of the antigen (Figure 2) protein was 0.54 $\mathrm{mg} / \mathrm{mL}$, the highest was $72 \mathrm{mg} / \mathrm{mL}$, and the average was 0.675 $\mathrm{mg} / \mathrm{mL}$ with SEM 0.118 .

The effect of the treatment with the crude TGP of $S$. calcitrans on the IgG levels in the serum of foals is presented in Figure 3. The data in Figure 3 above shows that the serum IgG level in experiment animals treated with crude TGP of $S$. calcitrans was significantly higher $(\mathrm{P}<0.05)$ than the serum IgG level of the control animals.

\section{Discussion}

Crude TGP of $S$. calcitrans collected from populations in the area of Sentrum Agraris Lotta, Minahasa, Indonesia, contained an average of $0.675 \mathrm{mg} / \mathrm{mL}$ of antigen- 5 protein. It was used as an

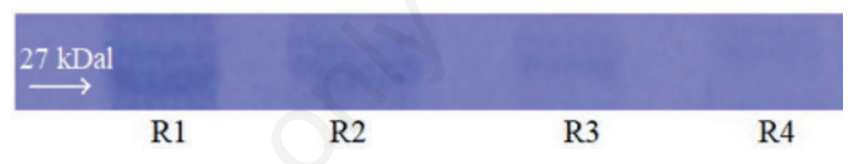

Figure 1. Identification of the antigen- 5 of crude thoraxial gland protein (TGP) extract of Stomoxys calcitrans by using electrophoresis with four R (replications).

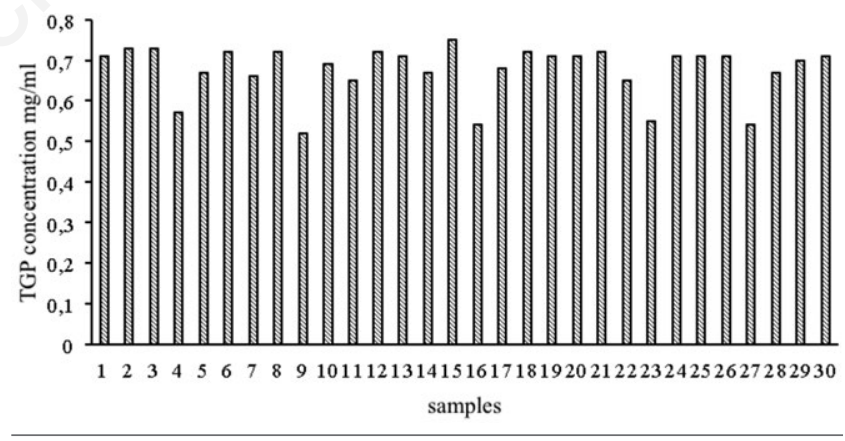

Figure 2. Levels of antigen protein in the crude thoraxial glandular protein (TGP) extract of Stomoxys calcitrans.

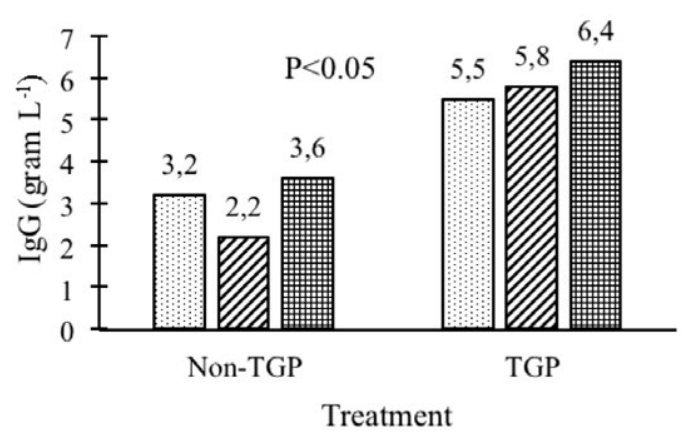

Figure 3. Levels of IgG in the serum of foals observed in the group treated with thoraxial glandular protein (TGP) compared those who did not receive the TGP treatment (non-TGP). 
immunogen for the experiment animals. This performance emphasized that substances from the saliva gland of flies are dominated by proteins of $27 \mathrm{kD}$ (Swist et al., 2002), and play an important role in the immune reaction in cattle (Torr \& Mangwiro, 2000).

The mean value of the serum $\mathrm{IgG}$ was higher in animals treated with a TGP injection than in control animals, showing that the effect of the TGP substance is to enhance the production and circulation of IgG antibodies, specifically illustrating the immune response to the antigen- 5 protein as described by Ueti et al. (2007). When an animal is treated with an antigen, this antigen can trigger the primary immune response causing the serum IgG to reach a peak 10 to 14 days after antigen exposure (Kresno, 1996), whereas if the antigen is absent, the primary immune response cannot occur.

The influence of TGP immunization by injection on $\operatorname{IgG}$ levels in the serum of foals in this research can provide a new hope to overcome the infection potency of pathogenic bacteria coming from the environment of the foals. This immune response is a consequence of the neonatal foals that are always born in hypo-globulinemia conditions, so that the effect of a TGP application as an immunogen has a positive role in increasing the neonatal serum antibody level. The result of this study on neonatal foals is in line with the work described by Ameri et al. (2008), which was done on calves. The efforts to increase such neonatal serum IgG antibody level are urgently needed in small-scale farming with traditionallybred animals as we can find it in many areas today (Joern \& Laws, 2013). The use of crude thoraxial glandular protein extract from these flies can be promoted as a means to overcome neonatal foals' high mortality rates, resulting from the failure in passive transfer (Rumokoy \& Toar, 2014). The effect of the antigen-5 of S. calcitrans in enhancing the production of antibodies which circulate in the blood allows to minimize the diseases caused by pathogen bacteria distributed by flies or other insects to other animals as reported by Pava-Ripoll et al. (2015) and Barro et al. (2006).

\section{Conclusions}

The crude thoraxial glandular protein extract obtained from $S$. calcitrans can be used to improve the IgG antibody circulation in foals. However it will be important to continue the research by evaluating the role of the thoraxial glandular protein on the specific $\mathrm{IgG}$ antibody production in foals.

\section{References}

AMERI M., WANG X., WILKERSON M.J. KANOST M.R., BROCE A.B., 2008 - An immunoglobulin binding protein (Antigen5) of the stable fly (Diptera: Muscidae) salivary gland stimulates bovine immune responses. - J. Med. Entomol. 45:94-101.

BALDACCHINO F., MUENWORN V., DESQUESNES M., et al., 2013 - Transmission of pathogens by Stomoxys flies (Diptera, Muscidae): a review. - Parasite 20: 26.

BARRO N., ALY S., TIDIANE O.C., SABABÉNÉDJO T.A., 2006 - Carriage of bacteria by proboscises, legs, and feces of two species of flies in street food vending sites in Ouagadougou, Burkina Faso. - J Food Prot. 69: 2007-2010.

BRITS D., BROOKS M., VILLET M.H., 2016 - Diversity of bacteria isolated from the Flies Musca domestica (Muscidae) and Chrysomya megacephala (Calliphoridae) with emphasis on vectored pathogens. - Afr. Entomol. 24: 365-75.
CUPP M.S., CUPP E.W., NAVARRE C., WISNEWSKI N., BRANDT K.S., SILVER G.M., ZHANG D., PANANGALA V., 2004 - Evaluation of a recombinant salivary gland protein (thrombostasin) as a vaccine candidate to disrupt blood-feeding by horn flies. - Vaccine 22: 2285-2297.

CUPP M.S., CUPP E.W., ZHANG D., ZHANG D., YUE X., TODD L., PANANGALA V., 2009 - Salivary gland thrombostasin isoforms differentially regulate blood uptake of horn flies fed on New Zealand White rabbits. - J. Med. Entomol. 46: 351-357.

GRACZYK T.K., KNIGHT R., GILMAN R.H., CRANFIELD M.R., 2001 - The role of non-biting flies in the epidemiology of human infectious diseases. - Microbes Infect. 3: 231-235.

GRONGNET J.F., 1996 - Quelques aspects de l'adaptation du ruminant nouveau-né à la vie aérienne. - Thèse de Doctorat. Ecole Nationale Supérieure Agronomique de Rennes, France.

JOERN A., LAWS A.N., 2013 - Ecological mechanisms underlying arthropod species diversity in grasslands. - Annu. Rev. Entomol. 58: 19-36.

KRESNO S.B., 1996 - Immunologi: Diagnosis dan Prosedur Laboratorium. - Fakultas Kedokteran Universitas Indonesia.

OBAME-NKOGHE J., RAHOLA N., AYALA D., YANGARI P., JIOLLE D., ALLENE X., BOURGAREL M., MAGANGA G., BERTHET N., LEROY E.M., PAUPY C., 2017 - Exploring the diversity of blood-suckling Diptera in caves of Central Africa. - Sci. Rep. 7: 250.

PAVA-RIPOLL M., PEARSON R.E., MILLER A.K., ZIOBRO G.C., 2015 - Detection of foodborne bacterial pathogens from individual filth flies. - J. Vis. Exp. 96: e52372.

RUMOKOY L., TOAR W.L., 2014 - The equine colostrum of milk treatment against pathogenic agent. - Scientific Paper. D. Anim. Sci. 57: 174-177.

RUMOKOY L., KAUNANG C., TOAR W.L., 2017 - Efek ekstrak minyak citronella Cymbopogon nardus L. terhadap proporsi frekuensi kontak fisik Musca domestica L. (Diptera: Muscidae) pada ransum dan performa broiler. - J. Ento. Ind. 14( 2): 89-96.

SWIST S.L., WILKERSON M.J., WYATT C.R., BROCE AB, KANOST MR., 2002 - Modulation of bovine lymphocyte response by salivary gland extracts of the stable fly, Stomoxys calcitrans (Diptera: Muscidae). - J. Med. Entomol 39: 900-907.

TALLEY J.L., WAYADANDE A.C., WASALA L.P., GERRY AC, FLETCHER J, DESILVA U, GILLILAND SE., 2009 Association of Escherichia coli O157:H7 with filth flies (Muscidae and Calliphoridae) captured in leafy greens fields and experimental transmission of E. coli $\mathrm{O} 157: \mathrm{H} 7$ to spinach leaves by house flies (Diptera: Muscidae). - J. Food Prot. 72: 1547-1552.

TAYLOR D.B., MOON R.D., CAMPBELL J.B., BERKEBILE D.R., SCHOLL P.J., BROCE A.B., HOGSETTE J.A., 2010 Dispersal of stable flies (Diptera: Muscidae) from larval development sites in a Nebraska landscape. - Environ. Entomol. 39: 1101-1110.

TOAR W.L., KAUNANG C., UNTU I.M., RUMOKOY L., KIROH H., 2017 - The empowerment of crude extraxt antigen$\mathrm{G}$ of insect on goats immunity enhancement. An Entomology Contribution in Animal Husbandry - Scientific Paper, Series D. Anim. Sci. 60: 271-273

TORR S.J., MANGWIRO T.N., 2000 - Interactions between cattle and biting flies: effects on the feeding rate of tsetse. - Med. Vet. Entomol. 14: 400-409.

UETI M.W., REAGAN J.O. Jr, KNOWLES D.P., SCOLES G.A., SHKAP V., PALMER G.H., 2009 - Identification of midgut and salivary glands as specific and distinct barriers to efficient 
tick-borne transmission of Anaplasma marginale. - J. Infect. Immunity 77: 70-75.

UNTALAN P.M., PRUETT J.H., ATTEBERRY H.N., STEELMAN C.D., 2006 - Thrombostasin isoform frequency in a Central Texas field population of the horn fly, Haematobia irritans. - Vet. Parasitol. 142: 359-366.

WANG X., RIBEIROB J., BROCEA M.C. et al., 2009 - An insight into the transcriptome and proteome of the salivary gland of the stable fly, Stomoxys calcitrans. - Insect. Biochem. Mol. Biol. 39: 607-614.

WASALA L., TALLEY J.L., DESILVA U., FLETCHER J, WAYADANDE A., 2013 - Transfer of Escherichia coli O157:H7 to Spinach by House Flies, Musca domestica (Diptera: Muscidae) - Phytopathology 103: 373-380.

ZAR J.H., 1996 - Biostatistical Analysis. - Third Edition PrenticeHall International, Inc. USA. 